\title{
Proses Demokrasi melalui Pilkada yang Berkualitas menuju Pemimpin Bali
}

\author{
Dewa Putu Mantera \\ Badan Kesatuan Bangsa dan Politik Provinsi Bali \\ email: kesbangpolbali@yahoo.co.id
}

\begin{abstract}
The general elections to choose regional leaders in the province of Bali is mandated by Undang-undang Nomor 10 Tahun 2016 tentang Pilkada (Law Number 10 Year 2016 about local leader election). Pilkada (pemilihan kepala daerah) or the local leader election based on the principle of democracy, they are "direct, general, free and secret, honest, and fair (langsung, umum, bebas dan rahasia, jujur dan adil or luberjurdil)" based on Pancasila and the 1945 constitution. Pilkada is the responsibility of the central government and local government so that the community can actively exercise their suffrage and obtain comprehensive information on the stages, profiles or figures, and capacity of Paslon (pasangan calon, the candidates). Selection of regional heads simultaneously in 2018 in the Province of Bali has been running safely, orderly, and successful so it is expected to produce a good Bali leader. This year the election is to choose the Governor and Vice Governor of Bali, the Bupati and Wakil Bupati (the head and vice head of the regency) in Gianyar Regency and Klungkung Regency.
\end{abstract}

Keywords: elections, pilkada, government, Bali.

\section{PENDAHULUAN}

Pemerintah kembali menggelar Pemilihan Kepala Daerah (Pilkada) secara serentak sebagai sarana pelaksanaan kedaulatan rakyat yang dilaksanakan berdasarkan prinsip demokrasi langsung, umum, bebas dan rahasia, jujur dan adil (luberjurdil) sesuai dengan Pancasila dan Undangundang Dasar 1945. Pilkada merupakan tanggung jawab seluruh Komponen Pemerintah Pusat dan Pemerintah Daerah sehingga masyarakat dapat menggunakan hak pilihanya sesuai hati nurani tanpa tekanan dari siapapun serta mendapatkan informasi yang jelas dan konprehensip atas tahapan, profil/figur serta kapasitas Paslon (pasangan calon). 
Pelaksanaan Pilkada secara serentak merupakan amanat dari Undang-undang (UU) Nomor 10 Tahun 2016 tentang Pilkada. Daerahdaerah yang melaksanakan Pilkada Serentak di seluruh Indonesia tahun 2018 adalah sebanyak 171 daerah terdiri atas 17 provinsi, 115 kabupaten, dan 39 kota. Pilkada serentak di Provinsi Bali tahun 2018 yang mencakup juga Pemilihan Gubernur dan Wakil Gubernur Bali, adalah pemilihan Bupati dan Wakil Bupati Gianyar serta Pemilihan Bupati dan Wakil Bupati Klungkung.
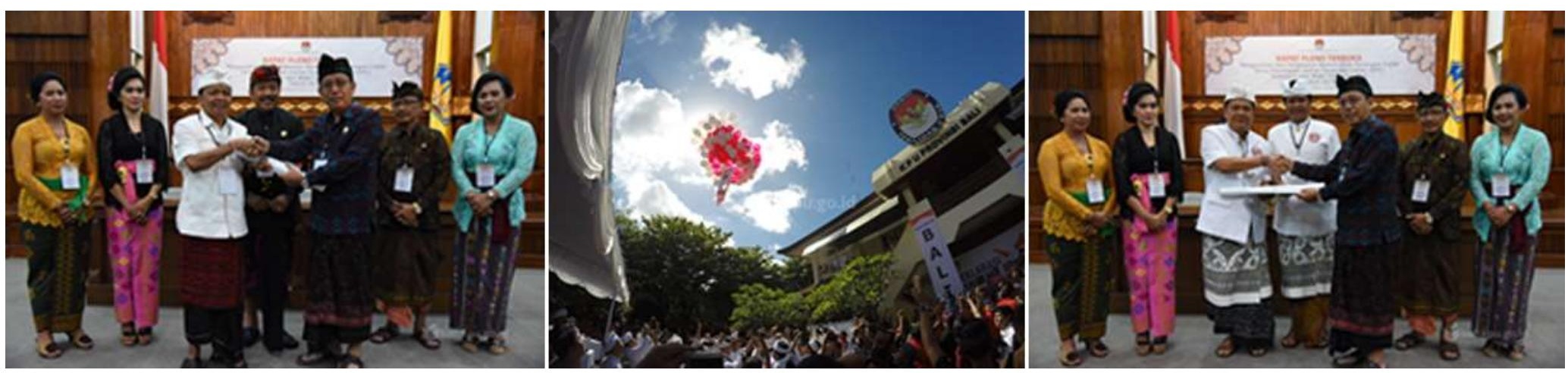

Pilkada merupakan proses demokrasi di tingkat daerah, sehingga kontestasi ini diharapkan melahirkan pemimpin-pemimpin yang membawa kemajuan bagi daerahnya masing-masing. Hal ini menjadi harapan kita bersama sebagai masyarakat Bali. Apabila proses Pilkada berjalan dengan baik dan semua pihak saling mendukung maka Pilkada dapat menghasilkan pemimpin yang baik. Selain menghasilkan pemimpin yang baik, penyelenggaraan Pilkada juga menggambarkan bagaimana demokrasi di daerah berjalan baik dan berkualitas. Itu merupakan harapan kita bersama sehingga kita semakin dewasa, santun, berintegritas, dan demokrasi akan tumbuh semakin baik. Hal ini membutuhkan rasa kebersamaan untuk mensukseskan pelaksanaan Pilkada yang semakin berkualitas. Suksesnya penyelenggaraan Pilkada di Provinsi Bali tahun 2018 juga dipengaruhi oleh kinerja yang baik dari aparat pemerintah, penyelenggara pemilu, aparat keamanan dan yang lainnya. Para pemimpin daerah seharusnya ikut melaksanakan tugas sebaik-baiknya untuk menyukseskan Pilkada. Di samping itu, para peserta dan elit politik juga bertanggung jawab untuk mewujudkan suksesnya pelaksanaan Pilkada. 
Dengan kata lain bahwa indikator untuk mewujudkan Pilkada serentak tahun 2018 yang berkualitas antara lain seperti indepedensi penyelenggara Pilkada daerah, pentingnya indepedensi birokrasi, partisipasi pemilih yang tinggi disertai kesadaran dan kejujuran dalam menentukan pilihannya, peserta pemilu melakukan proses penjaringan bakal calon yang demokratis dan berkualitas serta tidak menggunakan politik uang, dan terpilihnya kepala daerah hasil pemilihan demokratis oleh masyarakat, memiliki legitimasi yang kuat dan berkualitas.

Bila proses demokrasi tersebut berjalan dengan sempurna, maka kepala daerah yang dihasilkan dari proses tersebut adalah kepala daerah yang diharapkan masyarakat, yang mampu memajukan daerahnya. Selain kerjasama antar semua pihak Pilkada juga harus dilaksanakan sesuai tahapan dan tepat waktu, sesuai ketentuan peraturan perundang-undangan.

Pelaksanaan demokrasi melalui Pilkada serentak di Provinsi Bali tahun 2018 yang diselenggarakan pada tanggal 27 Juni 2018 pada prinsipnya telah berjalan aman, lancar, dan sukses. Dari sisi partisipasi pemilih cukup besar yaitu 72,09\%. Dari sisi pelaksanaan, Pilkada berjalan lancar, aman dan tertib termasuk dari aspek kesiapan dan pendistribusian logistik sudah berjalan dengan lancar sesuai mekanisma dan waktu yang telah ditentukan. Suksesnya Pilkada serentak tahun 2018 juga tidak terlepas dari peran Kepolisian, TNI, BIN, dan Satpol PP yang mendukung keamanan dan kenyamanan penyelenggaraan Pilkada tersebut. Tentunya tidak kalah pentingnya suksesnya pelaksanaan Pilkada yang disebabkan oleh peran Penyelenggara Pemilu, yakni Komisi Pemilihan Umum (KPU) dan Jajarannya dan Badan Pengawas Pemilu (Bawaslu) dan jajarannya, Kesbangpol Provinsi Bali dan jajarannya serta unsur media serta masyarakat dan pihakpihak terkait lainnya.

Ada pun dukungan pemerintah dalam pelaksanaan Pilkada tahun 2018 berupa pertama, dukungan data kependudukan. Dukungan data kependudukan telah dilakukan kesepakatan melalui MoU dan PKS antara Kementerian Dalam Negeri dengan KPU dalam rangka pemanfaatan dan akses data kependudukan secara online. 
Kedua, dukungan koordinasi pemeliharaan keamanan dan ketertiban Pilkada. (a) Memetakan dan mengelola potensi konflik. Telah dilakukan bersama Bawaslu dan pihak terkait untuk memetakan dan mengelola potensi konflik, pelanggaran dan kerawanan dalam penyelenggaran Pilkada dengan harapan sebagai bentuk potensi kerawanan dapat diantisipasi, dan tercegah. (b) Melakukan kajian dan analisis. Melakukan kajian dan analisis untuk memenuhi kebutuhan publik dan stakeholders akan informasi yang akuran dan valid. (c) Melakukan koordinasi. Melakukan koordinasi dengan pihak TNI dan Polri dengan berpedoman kepada penyelenggaraan ketertiban, ketenteraman, yang dikeluarkan oleh Kapolri dan Mendagri. (d) Memantapkan koordinasi. Memantapkan koordinasi horizontal dan vertical pada aspek-aspek yang dapat mengganggu pelaksanaan Pilkada tahun 2018.
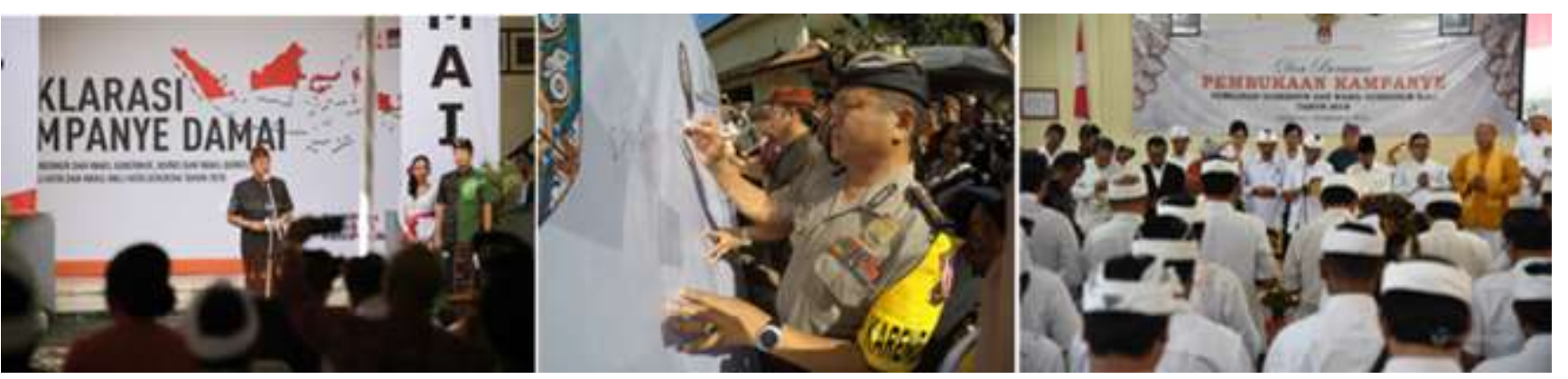

Ketiga, dukungan teknis kelancaran penyelenggaraan Pilkada. (a) Pembentukan regulasi teknis pelaksanaan Pilkada. (b) Sosialisasi Pilkada. (c) Monitoring kelancaran pelaksnaan tahapan Pilkada. (d) Pembentukan desk Pilkada di setiap daerah. (e) Meningkatkan pengawasan, pemantauan dan evaluasi pelaksanaan perlindungan anak secara berkelanjutan. (f) Kelancaran transportasi pengiriman logistik.

Keempat, dukungan peningkatan partisipasi pemilih. (a) Sosialisasi teknis pemilihan oleh SKPD terkait, pemerintah daerah yang melaksanakan Pilkada melalui SKPD wajib menyelaraskan kebijakan pemerintah pusat. (b) Menentukan hari libur kepada masyarakat pada saat pemungutan suara, dengan menentukan tanggal dan bulan pelaksanaan pemungutan suara agar pemilih dapat menggunakan hak pilihannya. (c) Memberikan pemahaman 
kepada pemilih untuk peduli dan berpartisipasi pada pelaksanaan Pilkada, agar masyarakat bisa mendapatkan iklim yang kondusif pada saat pesta rakyat di Provinsi Bali. (d) Mensosialisasikan pentingnya Pilkada melalui media cetak dan elektronik yang menjadi penentu bagi tingkat partisipasi pemilih dalam Pilkada.

Kelima, menjaga netralitas ASN di daerah. (a) Borkoordinasi dengan Menteri Pendayagunaan Aparatur Negara dan Reformasi Birokrasi. (b) Menegakkan sanksi terhadap pelanggaran ASN. (c) Menegakkan larangan menggunakan fasilitas pemerintah daerah untuk kepentingan kampanye. (d) Menyebarluaskan aturan terkait netralitas ASN. Terhadap ASN yang melanggar disiplin netralitas berdasarkan Pasal 33 ayat (2) Undang-undang Nomor 5 Tahun 2014 tentang Aparatur Sipil Negara akan menjatuhkan sanksi terhadap PPK.

\section{PEMBAHASAN}

Penyelenggaraan Pilkada di Bali didukung dengan pendanaan yang bersumber dari APBD Daerah masing-masing, yaitu Pilkada untuk Pemilihan Gubernur dan Wakil Gubernur Bali: Dana Pilkada untuk KPU Provinsi Bali sebesar Rp. 185.313.126.000,00, Dana Pilkada untuk Bawaslu Provinsi Bali Rp 39.000.000.000,00, Dana Pilkada untuk Polda Bali Rp 50.000.000.000,00, dan dana Pilkada untuk Korem 163 Wira Satya Rp 5.000.000.000,00.

Dalam tahapan Pilkada serentak yang telah dijadwalkan terdapat masing-masing dua pasangan calon yang mendaftar dalam Pemilihan Gubernur dan Wakil Gubernur Bali, Pemilihan Bupati dan Wakil Bupati Klungkung serta Pemilihan Bupati dan Wakil Bupati Klungkung.

Dalam Pemilihan Gubernur dan Wakil Gubernur Bali tahun 2018, pasangan calon nomor urut 1 adalah dengan nama pasangan calon: Calon Gubernur Bali: Dr. Ir. Wayan Koster, M.M. dan Calon Wakil Gubernur Bali: Dr. Ir. Tjok Oka Artha Ardhana, Sukawati, M.Si., didaftarkan oleh Dewan Pimpinan Daerah dan/atau Dewan Pimpinan Wilayah atau sebutan lain Gabungan Partai Politik yang meliputi: Partai Demokrasi Indonesia 
Perjuangan dengan perolehan 24 kursi/882.555 suara sah, Partai Amanat Nasional dengan perolehan 1 kursi/ 26.005 suara sah, Partai Keadilan dan Persatuan Indonesia dengan perolehan 1 kursi/55.966 suara sah, dan Partai Hati Nurani Rakyat perolehan 1 kursi/109.973 suara sah. Jumlah keseluruhan kursi atau suara sah sebanyak 27 kursi, telah memenuhi syarat atau telah memenuhi paling sedikit $20 \%$ atau 11 kursi di DPRD Provinsi Bali.

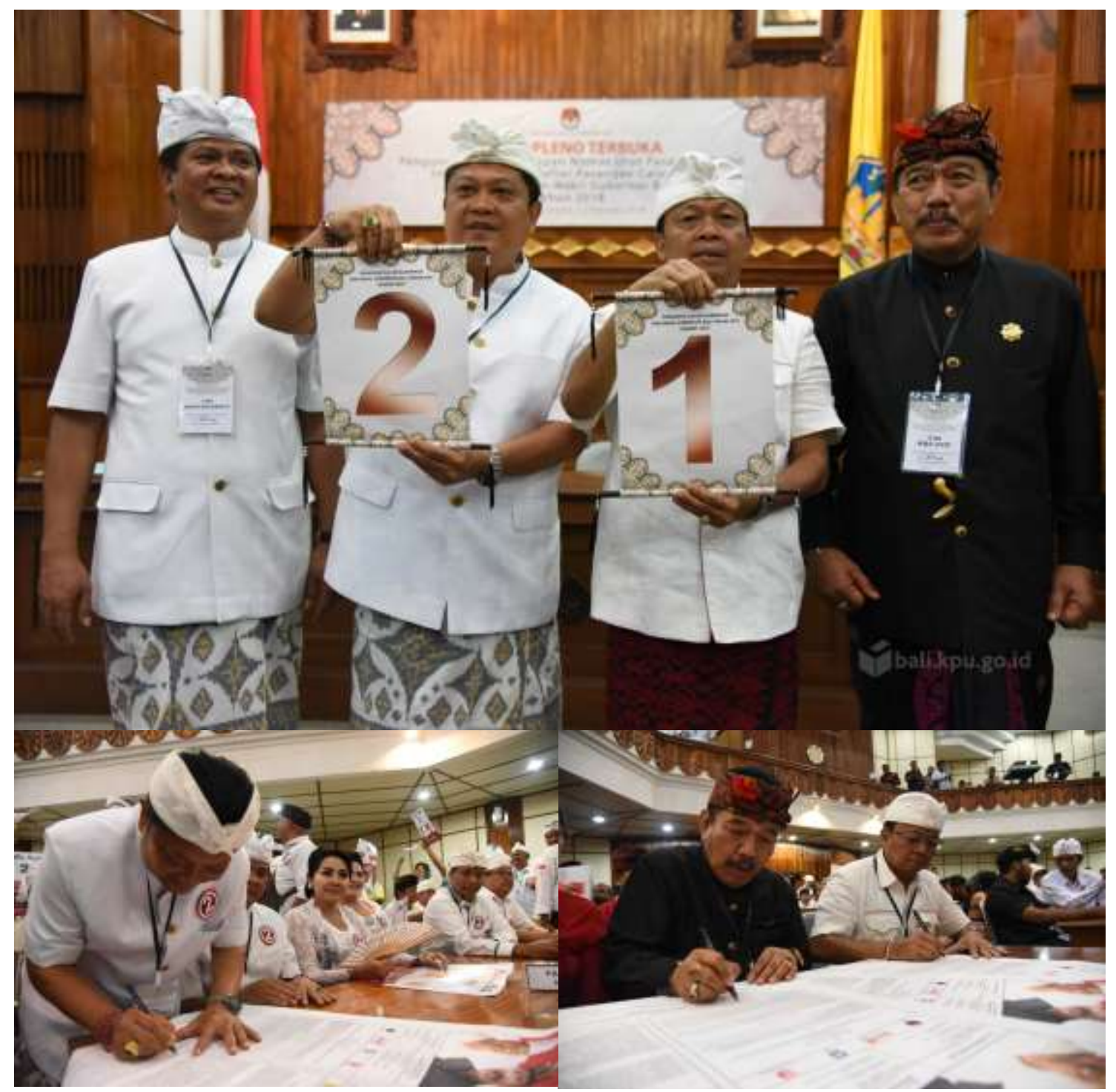

Pasangan Calon Nomor Urut 2 adalah dengan nama pasangan calon: Calon Gubernur Bali: Ida Bagus Rai Dharmawijaya Mantra, SE, M.Si, dan Calon Wakil Gubernur Bali: Drs. I Ketut Sudikerta didaftarkan oleh Dewan Pimpinan Daerah dan/atau Dewan Pimpinan Wilayah atau sebutan lain gabungan partai politik yang meliputi Partai Golkar dengan perolehan 11 
kursi, Partai Demokrat dengan perolehan 8 kursi, Partai Gerakan Indonesia Raya dengan perolehan 7 kursi, dan Partai NasDem dengan perolehan 2 kursi. Jumlah keseluruhan sebanyak 28 kursi dan telah memenuhi syarat pencalon atau paling sedikit $20 \%$ dari jumlah kursi DPRD Provinsi Bali, sebanyak 11 kursi.

Setelah dilaksanakan Kampanye dari tanggal 15 Pebruari sampai dengan 23 Juni, selanjutnya pemilihan dilaksanakan pada tanggal 27 Juni 2018 dan dari perhitungan cepat melalui situng KPU maka didapatkan gambaran sebagai berikut.

Hasil perhitungan (situng) cepat Pilkada serentak tahun 2018 dengan hasil penetapan Provinsi Bali.

\section{$100.00 \%$}

\section{Perolehan suara pasangan calon}

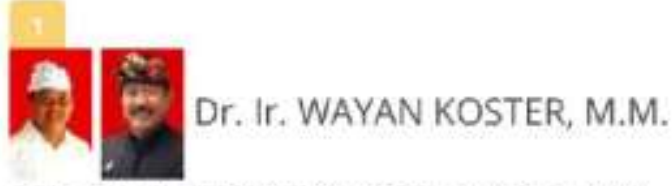

dan Dr. Ir. TJOK OKA ARTHA ARDHANA SUKAWATI, M.Si.

Perolehan suara

1.211.556 suara

$57.62 \%$

\section{Pemilih dan Pengguna Hak Pilih}

$\begin{array}{ll}\text { Pemilih } & \text { Laki-laki } \\ & 1.465 .844 \\ & \text { Laki-laki } \\ \begin{array}{l}\text { Pengguna Hak } \\ \text { Pilih }\end{array} & 1.063 .481 \\ & \text { Laki-laki } \\ \text { Partisipasi } & \end{array}$

2.

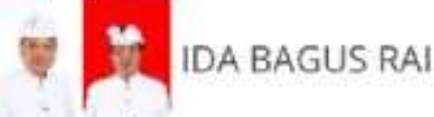

DHARMAWIJAYA MANTRA, S.E., M.Si dan DrS. I KETUT SUDIKERTA

Perolehan suara

891.178 suara

$42.38 \%$ 


\section{BADUNG >}

579/579 Pemilih dan pengguna hak pilih.

1 Pemilih

357.031

2. Pengguna Hak Pilih

284.888

3 Partisipasi

$79.8 \%$

Suara sah dan tidak sah.

1 Suarah sah

2. Suara tidak sah

3.619

3 Total suara

284,097

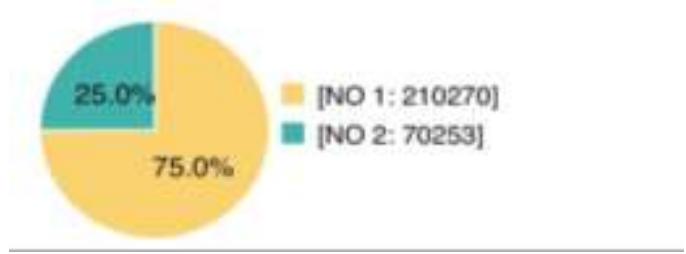

\section{BULELENG >}

Pemilih dan pengguna hak pilih.
1 Pemilih
556.418
z Pengguna Hak Pilih
326.013
3 Partisipasi
$58.6 \%$

Suara sah dan tidak sah.
1. Suarah sah
319.684
2 Suara tidak sah
4.781
3 Total suara
324.460

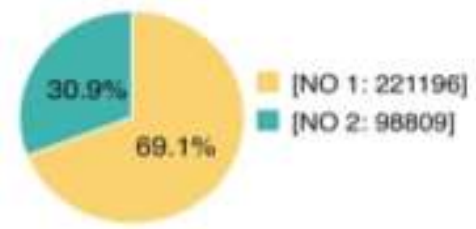

$\checkmark$ BANGLI >

467/46\% Pemilih dan pengguna hak pilih.

\begin{tabular}{|c|c|c|}
\hline 1 & Pemilih & 184.472 \\
\hline 2 & Pengguna Hak Pilih & 147,407 \\
\hline 3 & Partisipasi & $79.9 \%$ \\
\hline
\end{tabular}

Suara sah dan tidak sah.

I Suarah sah $\quad 144.443$

2 Suara tidak sah 2.976

3. Total suara $\quad 147.037$

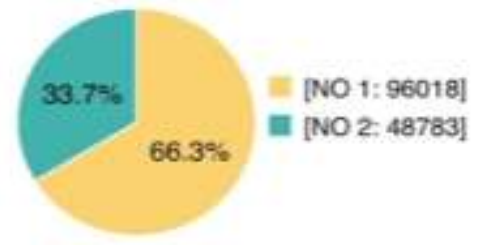

Suara sah dan tidak sah.

1. Suarah sah

287,344

2 Suara tidak sah

12.747

3 Total suara

300.105

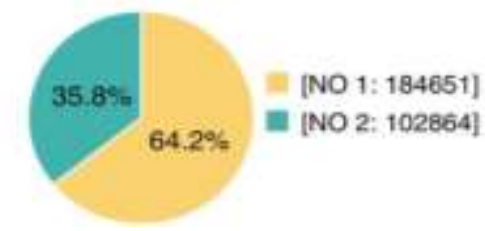


- JEMBRANA >

499/499 Pemilih dan pengguna hak pilih.

1 Pernilih

2 Pengguna Hak Pilih

3. Partisipasi

Suara sah dan tidak sah.

1 Suarah sah

2 Suara tidak sah

3 Total suara

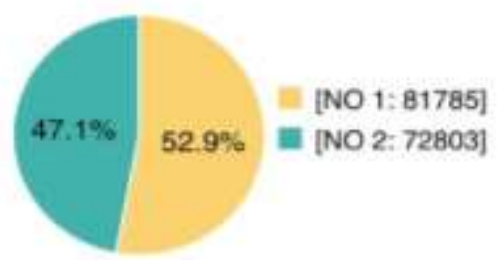

225.725

156.013

$69.1 \%$

154.594

1.636

156.280

\section{- KLUNGKUNG >}

350/350 Pemilih dan pengguna hak pilih.
1 Pernillh
155.930
2 Pengguna Hak Pilih
3 Partisipasi
125.042
$80.2 \%$

Suara sah dan tidak sah.
120.833

4.263

125.161

\section{KARANGASEM >}

945/945 Pemilih dan pengguna hak pilih.

1. Pemilih

372.442

2 Pengguna Hak Pilih

228.767

3 Partisipasi

$61.4 \%$

Suara sah dan tidak sah.

1 Suarah sah

222.857

2 Suara tidak sah

5.192

3 Total suara

227.639

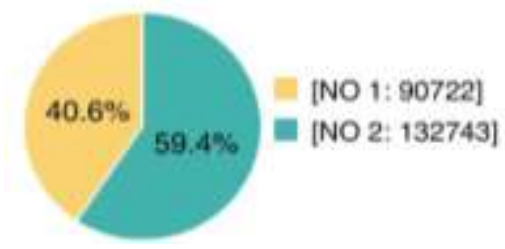

KOTA DENPASAR >

816/816 Pemilih dan pengguna hak pilih.

\begin{tabular}{|c|c|c|}
\hline 1 & Pemilih & 406.078 \\
\hline 2 & Pengguna Hak Pilih & 283.337 \\
\hline 3 & Partisipasi & $69.8 \%$ \\
\hline
\end{tabular}

Suara sah dan tidak sah.

1 Suarah sah

278.101

2. Suara tidak sah

5.009

3. Total suara

282.622
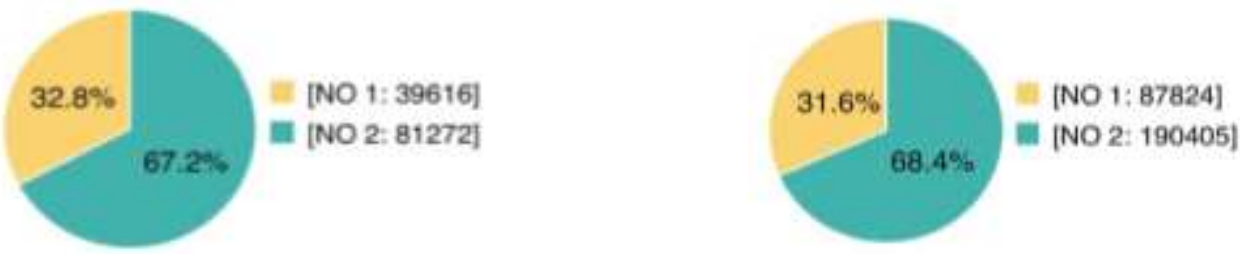


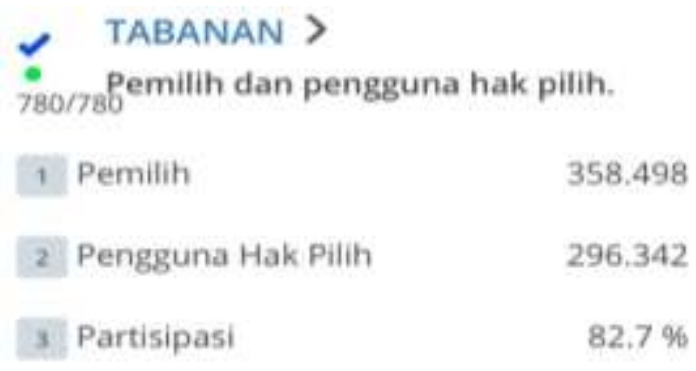

Suara sah dan tidak sah.

\begin{tabular}{lr}
1 Suarah sah & 292.635 \\
\hline 2. Suara tidak sah & 3.761 \\
3 Total suara & 296.394
\end{tabular}

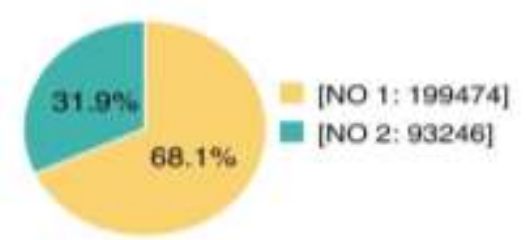

Sumber Data: Situng KPU.

Penetapan Perhitungan Suara Pemilihan Gubernur \& Wakil Gubernur Bali

\begin{tabular}{|c|c|c|c|c|c|c|c|c|c|c|c|c|}
\hline A & \multirow{2}{*}{\multicolumn{2}{|c|}{$\begin{array}{l}\text { Data Pemilih } \\
\text { dan } \\
\text { Penggunaan } \\
\text { Hak Pilih } \\
\text { Data Pemilih }\end{array}$}} & $\begin{array}{l}\text { Ba- } \\
\text { dung }\end{array}$ & Bangli & $\begin{array}{c}\text { Bu- } \\
\text { leleng }\end{array}$ & $\begin{array}{l}\text { Gia- } \\
\text { nyar }\end{array}$ & $\begin{array}{l}\text { Jem- } \\
\text { brana }\end{array}$ & $\begin{array}{l}\text { Ka- } \\
\text { rang- } \\
\text { asem }\end{array}$ & $\begin{array}{l}\text { Klung- } \\
\text { kung }\end{array}$ & $\begin{array}{l}\text { Kota } \\
\text { Den- } \\
\text { pasar }\end{array}$ & $\begin{array}{c}\text { Taba- } \\
\text { nan }\end{array}$ & $\begin{array}{l}\text { Jum- } \\
\text { lah } \\
\text { Akhir }\end{array}$ \\
\hline$A$ & & & \multicolumn{10}{|c|}{ Data Pemilih } \\
\hline \multirow[t]{9}{*}{1} & $\begin{array}{l}\text { 1. Pemilih } \\
\text { dalam } \\
\text { DPT }\end{array}$ & $\begin{array}{l}\mathrm{L} \\
\mathrm{K}\end{array}$ & $\begin{array}{l}176, \\
955\end{array}$ & $\begin{array}{r}92 \\
534\end{array}$ & $\begin{array}{r}279 \\
849\end{array}$ & $\begin{array}{r}180, \\
808\end{array}$ & $\begin{array}{l}111 \\
834\end{array}$ & $\begin{array}{r}190, \\
256\end{array}$ & $\begin{array}{c}77, \\
395\end{array}$ & $\begin{array}{r}201 \\
768\end{array}$ & $\begin{array}{r}176, \\
423\end{array}$ & $\begin{array}{r}1, \\
487 \\
822\end{array}$ \\
\hline & $\begin{array}{l}\text { (Model } \\
\text { A3-KWK) }\end{array}$ & $\begin{array}{l}P \\
R\end{array}$ & $\begin{array}{c}181 \\
170\end{array}$ & $\begin{array}{c}181 \\
170\end{array}$ & $\begin{array}{r}275 \\
706\end{array}$ & $\begin{array}{r}182 \\
276\end{array}$ & $\begin{array}{l}113 \\
817\end{array}$ & $\begin{array}{r}186 \\
496\end{array}$ & $\begin{array}{l}79 \\
106\end{array}$ & $\begin{array}{r}202 \\
571\end{array}$ & $\begin{array}{l}181 \\
731\end{array}$ & $\begin{array}{r}1 \\
494 \\
379\end{array}$ \\
\hline & & $\begin{array}{l}J \\
M \\
L\end{array}$ & $\begin{array}{r}358 \\
125\end{array}$ & $\begin{array}{r}358 \\
125\end{array}$ & $\begin{array}{r}555 \\
555\end{array}$ & $\begin{array}{r}363 \\
084\end{array}$ & $\begin{array}{r}225 \\
651\end{array}$ & $\begin{array}{r}376, \\
752\end{array}$ & $\begin{array}{c}156 \\
501\end{array}$ & $\begin{array}{r}404 \\
339\end{array}$ & $\begin{array}{r}358, \\
154\end{array}$ & $\begin{array}{r}2 \\
982 \\
201\end{array}$ \\
\hline & $\begin{array}{l}\text { 2.Pemilih } \\
\text { dalam }\end{array}$ & $\begin{array}{l}\mathrm{L} \\
\mathrm{K}\end{array}$ & 136 & 133 & 443 & 70 & 118 & 203 & 253 & 196 & 184 & $\begin{array}{r}1 \\
736\end{array}$ \\
\hline & $\begin{array}{l}\text { Dpph } \\
\text { (Model }\end{array}$ & $\begin{array}{l}\mathrm{P} \\
\mathrm{R}\end{array}$ & 77 & 38 & 179 & 53 & 44 & 124 & 91 & 192 & 82 & 880 \\
\hline & A4-KWK) & $\begin{array}{l}J \\
M \\
L\end{array}$ & 213 & 171 & 622 & 123 & 162 & 327 & 344 & 338 & 266 & $\begin{array}{r}2 \\
616\end{array}$ \\
\hline & $\begin{array}{l}\text { 3. Pemilih } \\
\text { dalam }\end{array}$ & $\begin{array}{l}\mathrm{L} \\
\mathrm{K}\end{array}$ & $\begin{array}{r}3 \\
209\end{array}$ & 470 & $\begin{array}{r}2 \\
338\end{array}$ & $\begin{array}{r}1, \\
436\end{array}$ & 705 & $\begin{array}{r}1 \\
133\end{array}$ & 764 & $\begin{array}{r}5 \\
116\end{array}$ & $\begin{array}{r}1, \\
043\end{array}$ & $\begin{array}{r}16 \\
214\end{array}$ \\
\hline & $\begin{array}{l}\text { DPTb/KT } \\
\text { P-el/Surat }\end{array}$ & $\begin{array}{l}P \\
R\end{array}$ & $\begin{array}{r}3 \\
746\end{array}$ & 578 & $\begin{array}{r}2 \\
119\end{array}$ & $\begin{array}{r}2 \\
008\end{array}$ & 783 & $\begin{array}{r}1 \\
095\end{array}$ & $\begin{array}{r}1 \\
062\end{array}$ & $\begin{array}{r}5 \\
693\end{array}$ & $\begin{array}{r}1, \\
285\end{array}$ & $\begin{array}{r}18 \\
369\end{array}$ \\
\hline & $\begin{array}{l}\text { Ketera- } \\
\text { ngan } \\
\text { (Model }\end{array}$ & $\begin{array}{l}J \\
M \\
L\end{array}$ & $\begin{array}{r}6 \\
955\end{array}$ & $\begin{array}{r}1 \\
048\end{array}$ & $\begin{array}{r}4, \\
457\end{array}$ & $\begin{array}{r}3 \\
444\end{array}$ & $\begin{array}{r}1 \\
488\end{array}$ & $\begin{array}{r}2, \\
228\end{array}$ & $\begin{array}{r}1 \\
826\end{array}$ & $\begin{array}{r}10 \\
809\end{array}$ & $\begin{array}{r}2, \\
328\end{array}$ & $\begin{array}{r}34, \\
583\end{array}$ \\
\hline
\end{tabular}




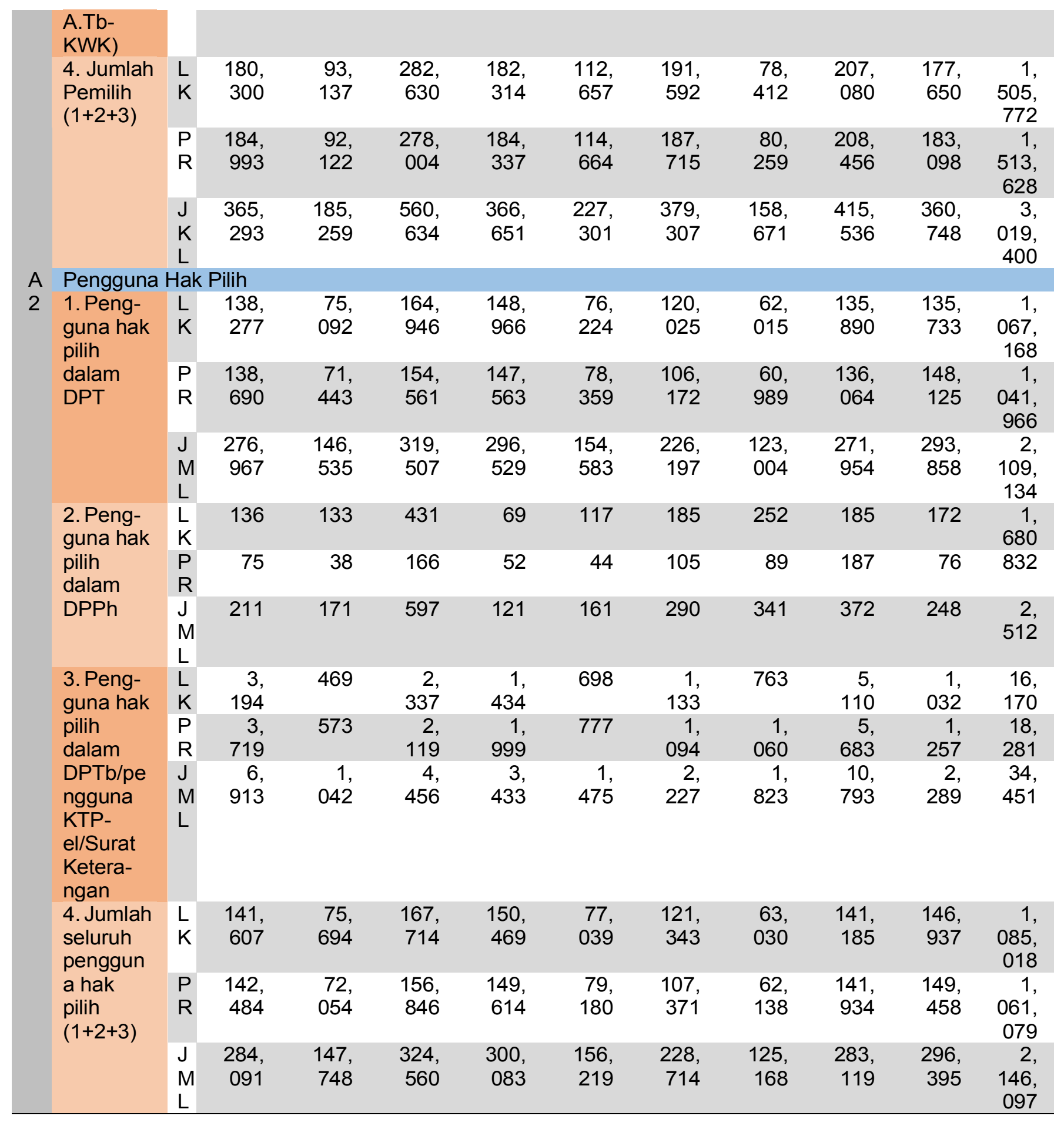




\begin{tabular}{|c|c|c|c|c|c|c|c|c|c|c|c|c|}
\hline \multirow{2}{*}{$\begin{array}{l}\text { N } \\
\text { O } \\
\text { B } \\
\text {. }\end{array}$} & \multirow{2}{*}{\multicolumn{2}{|c|}{$\begin{array}{c}\text { Uraian } \\
\text { Data Pemilih } \\
\text { dan } \\
\text { Penggunaan Hak } \\
\text { Pilih }\end{array}$}} & \multicolumn{10}{|c|}{ Rincian } \\
\hline & & & $\begin{array}{l}\text { Ba- } \\
\text { dung }\end{array}$ & $\begin{array}{l}\text { Bang- } \\
\text { li }\end{array}$ & $\begin{array}{l}\text { Bule- } \\
\text { leng }\end{array}$ & $\begin{array}{l}\text { Gia- } \\
\text { nyar }\end{array}$ & $\begin{array}{l}\text { Jem- } \\
\text { brana }\end{array}$ & $\begin{array}{l}\text { Ka- } \\
\text { Rang- } \\
\text { asem }\end{array}$ & $\begin{array}{c}\text { Klun } \\
\text { g } \\
\text { kung }\end{array}$ & $\begin{array}{c}\text { Kota } \\
\text { Denp } \\
\text { asar }\end{array}$ & $\begin{array}{l}\text { Ta- } \\
\text { ba- } \\
\text { nan }\end{array}$ & $\begin{array}{c}\text { Jum- } \\
\text { lah } \\
\text { Akhir }\end{array}$ \\
\hline \multirow[t]{7}{*}{1} & \multirow{4}{*}{$\begin{array}{l}\quad 1 \\
\text { 1. Pemilih } \\
\text { desabilitas/ } \\
\text { penyandang } \\
\text { cacat }\end{array}$} & & 3 & 4 & 5 & 6 & 7 & 8 & 9 & 10 & 11 & 18 \\
\hline & & $\begin{array}{l}\mathrm{L} \\
\mathrm{K}\end{array}$ & 133 & 42 & 133 & 110 & 48 & 601 & 85 & 74 & 314 & 1,540 \\
\hline & & $\begin{array}{l}P \\
R\end{array}$ & 143 & 30 & 66 & 67 & 40 & 516 & 43 & 48 & 270 & 1,223 \\
\hline & & $\begin{array}{l}J \\
M \\
L\end{array}$ & 275 & 72 & 199 & 177 & 88 & 1,117 & 128 & 122 & 584 & 2,763 \\
\hline & \multirow{3}{*}{$\begin{array}{l}\text { 2. Pemilih } \\
\text { desabilitas/ } \\
\text { penyandang } \\
\text { cacat } \\
\text { yang } \\
\text { menggunakan } \\
\text { hak pilih }\end{array}$} & $\mathrm{L}$ & 86 & 29 & 45 & 80 & 26 & 65 & 57 & 62 & 121 & 571 \\
\hline & & $\begin{array}{l}P \\
R\end{array}$ & 90 & 20 & 37 & 42 & 15 & 30 & 21 & 40 & 76 & 371 \\
\hline & & $\begin{array}{l}J \\
M \\
L\end{array}$ & 176 & 49 & 82 & 122 & 41 & 95 & 78 & 102 & 197 & 942 \\
\hline
\end{tabular}

\begin{tabular}{|c|c|c|c|c|c|c|c|c|c|c|c|}
\hline $\mathrm{N}$ & Uraian & & & & & Rincie & & & & & \\
\hline C & $\begin{array}{l}\text { Data Pemilih } \\
\text { dan } \\
\text { Penggunaan } \\
\text { Hak Pilih }\end{array}$ & $\begin{array}{l}\text { Ba- } \\
\text { dung }\end{array}$ & $\begin{array}{c}\text { Bang- } \\
\text { li }\end{array}$ & $\begin{array}{l}\text { Bu- } \\
\text { le- } \\
\text { leng }\end{array}$ & $\begin{array}{l}\text { Gia- } \\
\text { nyar }\end{array}$ & $\begin{array}{l}\text { Jem- } \\
\text { bra- } \\
\text { na }\end{array}$ & $\begin{array}{l}\text { Kara- } \\
\text { nga- } \\
\text { sem }\end{array}$ & $\begin{array}{l}\text { Klung- } \\
\text { kung }\end{array}$ & $\begin{array}{l}\text { Kota } \\
\text { Den- } \\
\text { pa- } \\
\text { sar }\end{array}$ & $\begin{array}{l}\text { Ta- } \\
\text { ba- } \\
\text { nan }\end{array}$ & $\begin{array}{c}\text { Jum- } \\
\text { lah } \\
\text { Akhir }\end{array}$ \\
\hline 1 & $\begin{array}{l}\text { Jumlah surat } \\
\text { suara yang } \\
\text { diterima } \\
\text { termasuk } \\
\text { cadangan } \\
2,5 \%\end{array}$ & $\begin{array}{r}367 \\
384\end{array}$ & $\begin{array}{l}188 \\
856\end{array}$ & $\begin{array}{r}570 \\
029\end{array}$ & $\begin{array}{r}372 \\
522\end{array}$ & $\begin{array}{l}231 \\
649\end{array}$ & $\begin{array}{r}387 \\
095\end{array}$ & $\begin{array}{r}160 \\
607\end{array}$ & $\begin{array}{r}415 \\
055\end{array}$ & $\begin{array}{c}367 \\
678\end{array}$ & $\begin{array}{r}3, \\
060, \\
875\end{array}$ \\
\hline 2 & $\begin{array}{l}\text { Jumlah surat } \\
\text { suara } \\
\text { dikembalikan } \\
\text { oleh pemilih } \\
\text { karena rusak } \\
\text { dan/atau } \\
\text { keliru coblos } \\
2\end{array}$ & 73 & 41 & 307 & 237 & 114 & 119 & 135 & 139 & 93 & $\begin{array}{r}1, \\
288\end{array}$ \\
\hline 3 & $\begin{array}{l}\text { Jumlah surat } \\
\text { suara yang } \\
\text { tidak } \\
\text { digunakan } \\
\text { termasuk } \\
\text { sisa surat } \\
\text { cadangan }\end{array}$ & $\begin{array}{r}83 \\
220\end{array}$ & $\begin{array}{c}41 \\
067\end{array}$ & $\begin{array}{r}245 \\
162\end{array}$ & $\begin{array}{r}72 \\
202\end{array}$ & $\begin{array}{r}75 \\
286\end{array}$ & $\begin{array}{c}158 \\
262\end{array}$ & $\begin{array}{r}35 \\
304\end{array}$ & $\begin{array}{c}131 \\
797\end{array}$ & $\begin{array}{c}71 \\
190\end{array}$ & $\begin{array}{r}913, \\
490\end{array}$ \\
\hline 4 & $\begin{array}{l}\text { Jumlah surat } \\
\text { suara yang } \\
\text { digunakan }\end{array}$ & $\begin{array}{r}284 \\
091\end{array}$ & $\begin{array}{l}147 \\
748\end{array}$ & $\begin{array}{r}324 \\
560\end{array}$ & $\begin{array}{r}300 \\
083\end{array}$ & $\begin{array}{c}156 \\
219\end{array}$ & $\begin{array}{l}228 \\
714\end{array}$ & $\begin{array}{r}125 \\
168\end{array}$ & $\begin{array}{c}283 \\
119\end{array}$ & $\begin{array}{l}296 \\
395\end{array}$ & $\begin{array}{r}2, \\
146, \\
097\end{array}$ \\
\hline
\end{tabular}




\begin{tabular}{|c|c|c|c|c|c|c|c|c|c|c|c|}
\hline \multirow{2}{*}{$\begin{array}{l}\text { N } \\
\text { O. } \\
\text { D. }\end{array}$} & \multirow{2}{*}{$\begin{array}{c}\text { Uraian } \\
\text { Data Pemilih } \\
\text { dan } \\
\text { Penggunaan } \\
\text { Hak Pilih }\end{array}$} & \multicolumn{10}{|c|}{ Rincian } \\
\hline & & $\begin{array}{l}\text { Ba- } \\
\text { dung }\end{array}$ & $\begin{array}{c}\text { Bang- } \\
\mathrm{li}\end{array}$ & $\begin{array}{l}\text { Bule- } \\
\text { leng }\end{array}$ & $\begin{array}{l}\text { Gia- } \\
\text { nyar }\end{array}$ & $\begin{array}{c}\text { Jem- } \\
\text { bra- } \\
\text { na }\end{array}$ & $\begin{array}{c}\text { Ka- } \\
\text { ra- } \\
\text { nga- } \\
\text { sem }\end{array}$ & $\begin{array}{l}\text { Klung- } \\
\text { kung }\end{array}$ & $\begin{array}{l}\text { Kota } \\
\text { Den- } \\
\text { pasar }\end{array}$ & $\begin{array}{c}\text { Taba- } \\
\text { nan }\end{array}$ & $\begin{array}{l}\text { Jum- } \\
\text { lah } \\
\text { Akhir }\end{array}$ \\
\hline 1 & $\begin{array}{l}\text { Dr. Ir. } \\
\text { Wayan } \\
\text { Koster, M.M. } \\
\text { dan Dr. Ir. } \\
\text { Tjok. Oka } \\
\text { Artha } \\
\text { Ardhana } \\
\text { Sukawati, } \\
\text { M.Si. }\end{array}$ & $\begin{array}{r}210 \\
175\end{array}$ & $\begin{array}{r}96 \\
327\end{array}$ & $\begin{array}{r}220 \\
923\end{array}$ & $\begin{array}{r}186 \\
076\end{array}$ & $\begin{array}{r}81 \\
783\end{array}$ & $\begin{array}{r}90 \\
891\end{array}$ & $\begin{array}{r}39 \\
653\end{array}$ & $\begin{array}{c}87 \\
863\end{array}$ & $\begin{array}{c}199 \\
384\end{array}$ & $\begin{array}{r}1, \\
213, \\
075\end{array}$ \\
\hline 2 & $\begin{array}{l}\text { Ida Bagus } \\
\text { Rai Dharma- } \\
\text { wijaya } \\
\text { Mantra, S.E., } \\
\text { M.Si. dan } \\
\text { Drs. I Ketut } \\
\text { Sudikerta }\end{array}$ & $\begin{array}{l}70 \\
290\end{array}$ & $\begin{array}{r}48 \\
917\end{array}$ & $\begin{array}{r}98 \\
859\end{array}$ & $\begin{array}{r}101 \\
256\end{array}$ & $\begin{array}{r}72 \\
801\end{array}$ & $\begin{array}{r}132 \\
795\end{array}$ & $\begin{array}{r}81 \\
232\end{array}$ & $\begin{array}{c}190 \\
534\end{array}$ & $\begin{array}{r}94 \\
246\end{array}$ & $\begin{array}{r}889, \\
930\end{array}$ \\
\hline E. & $\begin{array}{l}\text { Jumlah } \\
\text { seluruh } \\
\text { suara sah }\end{array}$ & $\begin{array}{r}280 \\
465\end{array}$ & $\begin{array}{r}145 \\
244\end{array}$ & $\begin{array}{r}319 \\
782\end{array}$ & $\begin{array}{r}287 \\
332\end{array}$ & $\begin{array}{c}154 \\
584\end{array}$ & $\begin{array}{r}223 \\
686\end{array}$ & $\begin{array}{c}120, \\
885\end{array}$ & $\begin{array}{l}278 \\
387\end{array}$ & $\begin{array}{r}292 \\
630\end{array}$ & $\begin{array}{r}2, \\
103, \\
005\end{array}$ \\
\hline F. & $\begin{array}{l}\text { Jumlah } \\
\text { suara tidak } \\
\text { sah }\end{array}$ & $\begin{array}{r}3, \\
626\end{array}$ & $\begin{array}{r}2, \\
504\end{array}$ & $\begin{array}{r}4 \\
778\end{array}$ & $\begin{array}{r}12 \\
751\end{array}$ & $\begin{array}{r}1 \\
635\end{array}$ & $\begin{array}{r}5 \\
028\end{array}$ & $\begin{array}{r}4 \\
279\end{array}$ & $\begin{array}{r}4 \\
722\end{array}$ & $\begin{array}{r}3 \\
765\end{array}$ & $\begin{array}{r}43 \\
088\end{array}$ \\
\hline G & $\begin{array}{l}\text { Jumlah } \\
\text { seluruh } \\
\text { suara sah } \\
\text { dan tidak } \\
\text { sah }(E+F)\end{array}$ & $\begin{array}{r}284 \\
091\end{array}$ & $\begin{array}{c}147 \\
748\end{array}$ & $\begin{array}{r}324 \\
560\end{array}$ & & $\begin{array}{l}156 \\
219\end{array}$ & $\begin{array}{r}228 \\
714\end{array}$ & $\begin{array}{r}125 \\
164\end{array}$ & $\begin{array}{c}283 \\
119\end{array}$ & $\begin{array}{l}296 \\
395\end{array}$ & $\begin{array}{r}2, \\
146, \\
093\end{array}$ \\
\hline
\end{tabular}

Sumber Data : KPU Provinsi Bali

\section{KESIMPULAN}

Pilkada tahun 2018 dilaksanakan sebagai langkah strategis dalam membangun kualitas demokrasi di daerah, mengharuskan adanya independensi antar komponen stakeholder secara menyeluruh, sehingga upaya-upaya koordinasi dan konsolidasi segenap jajaran perlu senantiasa dilakukan dan dimantapkan. Perlu dilaksanakan sosialisasi serentak diberbagai level atau strata sosial masyarakat, sehingga seluruh lapisan masyarakat dapat berpartisipasi aktif dalam pelaksanaan pemungutan suara. Untuk menghasilkan pemimpin daerah yang berkualitas maka diawali dengan Pilkada yang berkualitas, melalui mekanisme dan tahapan sesuai dengan ketentuan yang berlaku. 


\section{DAFTAR PUSTAKA}

https://infopemilu.kpu.go.id.

Komisi Pemilihan Umum Provinsi Bali.

Majalah Media Praja Kementerian Dalam Negeri edisi 1 tahun 2017.

PKPU nomor 1-5 tentang Pilkada serentak tahun 2018.

PKPU Nomor 1 Tahun 2017 tentang Tahapan, Program dan Jadwal Penyelenggaraan Pemilihan Gubernur dan Wakil Gubernur, Bupati dan Wakil Bupati, dan/atau Walikota dan Wakil Walikota Tahun 2018.

PKPU Nomor 2 Tahun 2017 tentang Pemuktahiran Data dan Penyusunan Daftar Pemilih dalam Pemilihan Gubernur dan Wakil Gubernur, Bupati dan Wakil Bupati dan/atau Walikota dan Wakil Walikota Tahun 2018.

PKPU Nomor 3 Tahun 2017 tentang Pencalonan Pemilihan Gubernur dan Wakil Gubernur, Bupati dan Wakil Bupati, dan/atau Walikota dan Wakil Walikota Tahun 2018.

PKPU Nomor 4 Tahun 2017 tentang Kampanye Pemilihan Gubernur dan Wakil Gubernur, Bupati dan Wakil Bupati, dan/atau Walikota dan Wakil Walikota Tahun 2018.

PKPU Nomor 5 Tahun 2017 tentang Dana Kampanye Pemilihan Gubernur dan Wakil Gubernur, Bupati dan Wakil Bupati dan/atau Walikota dan Wakil Walikota Tahun 2018. 